\title{
Understanding ozone generation in electrochemical cells at mild pHs
}

M. Rodríguez-Peña ${ }^{1,2}$, J.A. Barrios Pérez ${ }^{2}$, J. Llanos ${ }^{1}$, C. Saez ${ }^{1}$, C.E. Barrera-Díaz ${ }^{2}$, M.A. Rodrigo ${ }^{1, *}$

${ }^{1}$ Department of Chemical Engineering. Faculty of Chemical Sciences and Technologies. University of Castilla La Mancha. Campus Universitario s/n. 13071 Ciudad Real. Spain.

${ }^{2}$ Facultad de Química. Universidad Autónoma del Estado de México, Paseo Colón intersección Paseo Tollocan S/N, C.P. 50120, Toluca, Estado de México, Mexico.

\begin{abstract}
In this work, the production of ozone at mild $\mathrm{pH}$ conditions using a commercial electrochemical PEM cell CONDIAPURE ® is evaluated, at once a phenomenological model is proposed to understand the basis of the processes that occur inside the cell. At these $\mathrm{pH}$ conditions, the production of ozone can be explained from the oxidation of water, while the decomposition of ozone is found to be extremely important to explain the global experimental behavior observed. Not only is this decomposition a chemical but also an electrochemically assisted process which, in turn, can be related to the production of other oxidants in the cell which interact with ozone behaving as predators. The model formulated explains and satisfactorily reproduces the influence of the operation mode, the current intensity applied and presence and destruction of organics, with regression coefficients $\left(\mathrm{r}^{2}\right)$ ranging from 0.88 to 0.99 , helping to understand how the production of ozone should be promoted during electrochemical processes.
\end{abstract}

\section{Keywords}


Electro-ozonator; operation mode; mild pHs; electrochemical advanced oxidation process

\section{Highlights}

- Ozone generation can be attained with PEM electrolyzers operating at mild pHs.

- Ozone production at mild $\mathrm{pHs}$ can be explained from the oxidation of water.

- Ozone is destroyed by interaction with predator species produced electrochemically.

- Degradation of clopyralid is attained by a cocktail of oxidants, including ozone.

- Good fitting of experimental observations to a simple phenomenological model.

*author to whom all correspondence should be addressed: manuel.rodrigo@uclm.es

\section{Introduction}


Ozone is a powerful oxidant with many applications in water and wastewater treatment, because this oxidant can rapidly and efficiently remove a large variety of organic pollutants and pathogens, showing a key advantage as compared with other oxidation processes: there is no direct harmful by-product formation associated to ozone action. Thus, ozone decomposes into oxygen $[1,2]$ during the treatments, in contrast with other highly oxidizing compounds such as chlorine [3,4], which lead to the formation of hazardous organochlorinated species.

Ozone can be generated by means of different technologies such as corona discharge, UV-light absorption, or electrical discharge ozone generators. However, these methods are known to have many disadvantages, such as the very high voltages required, the need of high-quality oxygen or air, and the extreme importance of the transfer of gaseous ozone to the water or wastewater in treatment, which lead to high operational costs. In addition, despite the generation of ozone is extremely energy intensive, around $90 \%$ of the power supplied to the generator dissipates, wasted in the production of light, sound and primarily heat, rather than being used in the production of ozone, [5-7]. In this context, the ozone electrogeneration is an attractive alternative that overcomes many of the difficulties of typical methods for generating ozone, because it allows working with lower voltages, generating the ozone directly in the liquid phase and, in addition, it does not need to feed pure oxygen or high-quality air to produce high concentrations of ozone with high energy yield [7,9-12]. Furthermore, ozone is generated from water and directly into water, preventing mass transfer problems and improving mineralization efficiency in wastewater treatment $[13,14]$.

The production of ozone in electrochemical cells has been reported in many previous works over recent decades $[11,15,16]$, though not much attention has been paid to the potential applications in wastewater treatment, and further work has been recommended as necessary to improve the potential applicability of the technology [17]. With the 
development of PEM electrolyzers [18] equipped with boron doped diamond anodes, there are new opportunities to improve ozone production and thereby, the environmental applicability of this novel technology [19-22]. These electrolyzers can even operate with very low conductivity water, because the ionic circuit between the anode and the cathode is not the treated water (or wastewater) but the polymer exchange membrane that connects both electrodes in the so-called membrane-electrode assembly (MEA).

One important point is that the concentration of ozone in the liquid phase seems to be limited by the solubility or the decomposition of this gas during the electrolytic process which, in turn, can be related to different operational conditions such as temperature and $\mathrm{pH}$ [23-25]. This has been a severe limitation for the development of the technology, in this sense, understanding the different phenomena involved in the generation of this oxidant, with a view to optimizing the performance of electro-ozonizers, is of the utmost importance.

In this work, the electrogeneration, stability and application of ozone is studied through a simple phenomenological model that explains the generation of ozone at mild $\mathrm{pHs}$ by oxidation of water in a PEM electrolyzer and describes the behavior under different operating conditions including those of the treatment of an organic pollutant.

\section{Materials and Methods}

Chemicals. Double de-ionized water (Millipore Milli-Q system, resistivity: $18.2 \mu \Omega \mathrm{cm}^{-1}$ at $25 \mathrm{C})$ was used to prepare water solutions. Sodium sulfate $\left(\mathrm{Na}_{2} \mathrm{SO}_{4}\right)$ was used as salt 
for the electrolyte. Methanol and formic acid (HPLC grade) were used to prepare the mobile phase in HPCL analysis (Sigma-Aldrich, Spain).

PEM electrolyzer and setup. The experiments were carried out in a CONDIAPURE® cell (supplied by Condias GMbH, Germany). This electrolyzer is equipped with two diamond electrodes and a proton exchange Nafion membrane. The surface of the diamond electrodes is $146 \mathrm{~cm}^{2}$. The electrolyzer is connected to reservoir tanks with a micropump GB-P25 J F5 S A head coupled to a DB 380 A $24 \mathrm{~V}$ engine (with speed control 0-5V DC) supplied by TechmaGPM s.l.r. (Milan, Italy). A picture of the experimental setups, with indication of the components, is shown in Figure 1. A Delta Elektronika ES030-10 power supply (Delta Elektronika, Netherlands) powered the cell.

Analytical techniques. The concentration of dissolved ozone was measured by the N,Ndiethyl-p-phenylenediamine (DPD) colorimetric method, using Spectroquant Merck test kits (Hach, Model: DR2000). Clopyralid concentration was monitored by High Performance Liquid Chromatography (HPLC) and Total Organic Carbon (TOC) using a Multi N/C 3100 Analytik Jena TOC analyzer. More details of these analytical techniques are offered elsewhere [26].

Experimental procedure. The tests were carried out in continuous and batch mode using a solution of $1 \mathrm{~g} \mathrm{~L}^{-1}$ of $\mathrm{Na}_{2} \mathrm{SO}_{4}$. In continuous mode, the solution flows from the reservoir tank to the cell and it is collected into a different tank. The flows studied in continuous mode were $0.5,1.0,1.5,3.0,4.0,7.0,10.0,15.0,18.0,24.0$ and $30.0 \mathrm{~L} \mathrm{~min}^{-1}$ and the applied current was 10 A for all the cases. In discontinuous operation mode, the solution is recirculated through the reservoir tank and the PEM cell at a constant flow of $3 \mathrm{~L} \mathrm{~min}^{-}$ ${ }^{1}$ and applying 10, 8 and $7 \mathrm{~A}$. In the organic pollutant oxidation tests, the solution was prepared with $100 \mathrm{mg} \mathrm{L}^{-1}$ of clopyralid. 


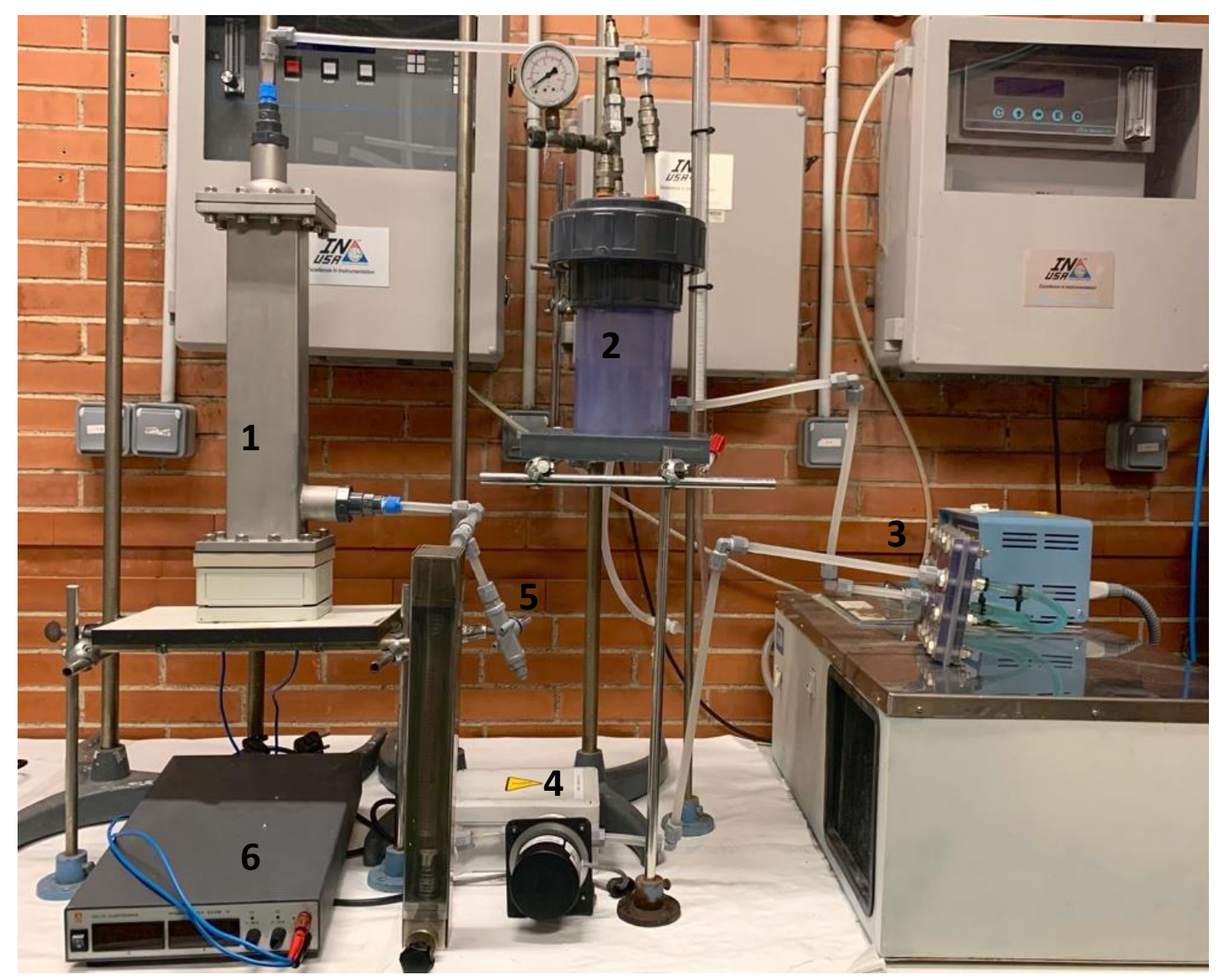

Figure 1. Experimental setup for the discontinuous mode: 1) reactor; 2) tank; 3) heat exchanger; 4) micropump; 5) sampling point; 6) power supply. 


\section{Results and discussion}

General behavior in the production of ozone. Figure 2 shows the concentration and amount of ozone produced during the electrolysis of a solution of sodium sulfate when a current intensity of $10 \mathrm{~A}$ is applied in continuous (part a) and discontinuous (part b) operation mode (current density $86.2 \mathrm{~mA} \mathrm{~cm}^{-2}$ ). A very important observation is that in continuous mode the concentration increases up to a plateau; while in discontinuous mode, it increases rapidly up to a maximum value, from which it decreases.

Usually, during the production of other oxidants with electrolyzers, the trend observed in discontinuous processes is very different [27-29], sharing the same initial stage with a very rapid increase in the concentration of the oxidant formed, followed by a plateau, which corresponds to a stage at which the rates of production and destruction of oxidants are balanced. This means that for an efficient full-scale production of ozone in this case, it would be required to remove rapidly the oxidant produced, since otherwise it will be destroyed above this concentration.
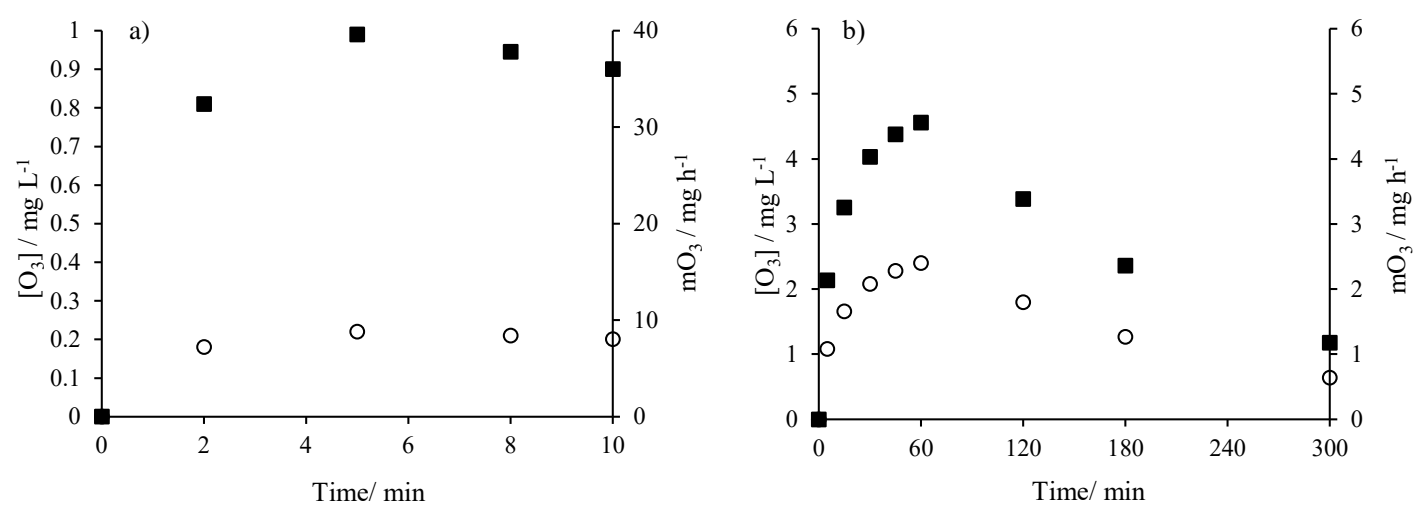

Figure 2. Ozone electrogeneration in continuous (part a) and discontinuous (part b) operation mode. $\mathbf{a m o u n t}\left(\mathrm{mg} \mathrm{h}^{-1}\right)$; ○ Concentration $\left(\mathrm{mg} \mathrm{L}^{-1}\right)$ (conditions: continuous mode flow $3 \mathrm{~L} \mathrm{~min}^{-1}$, $\left.\mathrm{pH} 6.8,10 \mathrm{~A}\right)$. 
Such destruction can be easily prevented in continuous processes, since the electrolyte is not recycled again into the cell, but it simply leaves the cell with the oxidant formed and hence, there is no way to electrochemically destroy the oxidant produced.

In this continuous mode of operation, the concentration of ozone does not increase with the flow rate, it is maintained in spite of the higher mass transfer coefficient associated to the higher flow rate that is expected to be reached. Moreover, the production of ozone leaving the cell (in amount, not in concentration) increases over time, owing to the higher flow rate that drags the ozone produced, as it is also displayed in Figure 3. This means that in order to obtain a higher amount of ozone, a continuous process should be used and the flow rate passing through the cell should be over a minimum value. Figure 3 shows the influence of the flow rate on the concentration of ozone produced in continuous mode.
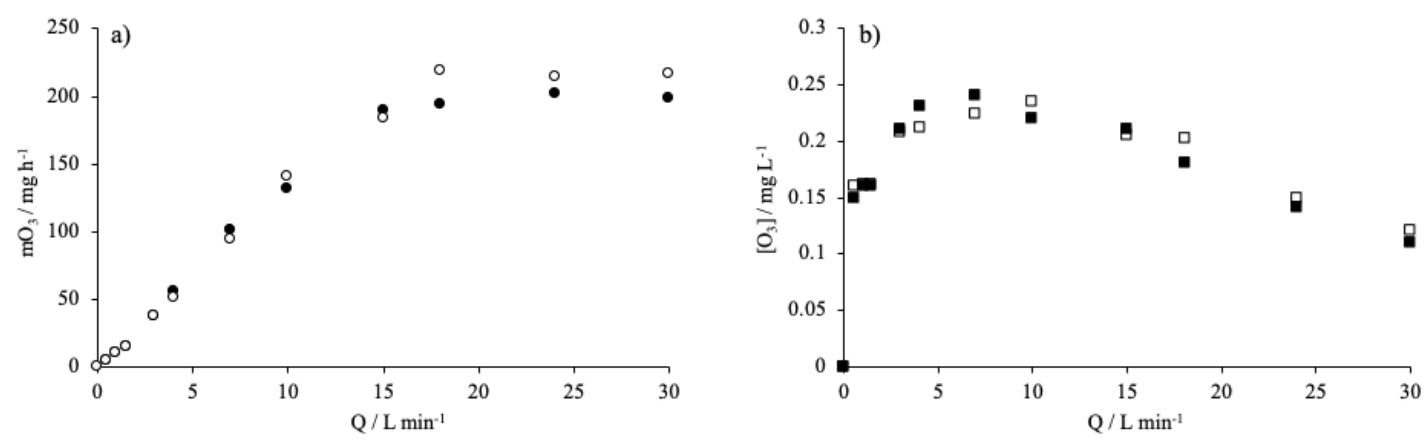

Figure 3. Influence of the flow rate on the amount (part a) and concentration (b) of ozone electrogenerated in continuous mode $(\mathrm{pH} 6.8,10 \mathrm{~A}) .(\bullet, \mathbf{\square})$ Experimental results;

$$
(\circ, \square) \text { model results. }
$$

Note that for low flow rates the amount of ozone contained in the stream that leaves the cell increases with the flow rate, up to reaching the maximum capacity of production of ozone in the cell. For the operating conditions and electrolyte used in this work, this maximum production is attained with flow rates over $15 \mathrm{~L} \mathrm{~min}^{-1}$ and it is around $200 \mathrm{mg}$ $\mathrm{h}^{-1}$. To understand this behavior, it is necessary to bear in mind that the specific charge applied to the system is lower for increasing flow rate values. Consequently, this result 
supports the key role of ozone destruction reactions and the existence of an optimal value of charge applied, from which parasitic reactions contribute to lower the concentration of ozone at the outlet of the cell.

Formulation of a model for the electrogeneration of ozone at mild pH conditions. To understand the experimental observations, as a first strategy to maximize the production of ozone, a phenomenological model is proposed. At mild $\mathrm{pH}$ conditions, the production of ozone from water follows the global reaction described in process $\mathrm{p}_{1}$, where the oxidation of water to produce ozone must compete with the easier production of oxygen (process $\mathrm{p}_{2}$ ) and with other direct anodic oxidation processes that will be described later.

$$
\begin{aligned}
& 3 \mathrm{H}_{2} \mathrm{O} \rightarrow \mathrm{O}_{3}+6 \mathrm{H}^{+}+6 \mathrm{e}^{-}\left(\mathrm{p}_{1}\right) \\
& 2 \mathrm{H}_{2} \mathrm{O} \rightarrow \mathrm{O}_{2}+4 \mathrm{H}^{+}+4 \mathrm{e}^{-}\left(\mathrm{p}_{2}\right)
\end{aligned}
$$

In a simplified way, both processes can be represented by a zero-order kinetic, according to equations (1) and (2), in which yield indicates the proportion of electric current that is used for producing ozone $\left(\eta_{\mathrm{a} 1}\right)$ or oxygen $\left(\eta_{\mathrm{a} 2}\right)$, respectively. Because of its lower oxidation potential ( $\mathrm{E}^{0}$ of $1.23 \mathrm{vs} 1.51 \mathrm{~V}$ for oxygen and ozone formation, respectively), the formation of oxygen would be promoted over the formation of ozone and initially, higher current densities are expected to promote a change in this ratio.

$$
\begin{aligned}
& r_{1}=\frac{I}{n_{1} F} \eta_{a 1}(1) \\
& r_{2}=\frac{I}{n_{2} F} \eta_{a 2}(2)
\end{aligned}
$$

Where $r_{i}$ is production rate; $I$ is current intensity (A); $n$, the number of electron transferred; $F$, Faraday's constant $\left(96487 \mathrm{C} \mathrm{mol}^{-1}\right)$; and, $\eta_{a i}$ is the anodic efficiency of the process. 
Regarding the decomposition of ozone, a more detailed representation is required. Ozone is known to decompose chemically to oxygen (process $\mathrm{p}_{3}$ ). In this context, the chemical and electrochemical decomposition of any oxidant, including ozone, usually fits well to a first-order kinetic with respect to the concentration of the oxidant contained in the electrolyte (Eq. 3).

$$
\begin{aligned}
& \mathrm{O}_{3} \rightarrow 3 / 2 \mathrm{O}_{2}\left(\mathrm{p}_{3}\right) \\
& r_{3}=-k_{3}\left[S_{1}\right](3)
\end{aligned}
$$

Where $r_{i}$ is production rate; $k_{i}$ is the constant rate of the process $\left(\mathrm{s}^{-1}\right)$; and, $\left[S_{i}\right]$ is product concentration $\left(\mathrm{mg} \mathrm{L}^{-1}\right)$

However, this simple model cannot fit well to what is observed in the experimental tests shown in this paper and should be complemented with other different processes, because its simulation leads to a stabilization in the concentration of ozone when an equilibrium concentration between the formation and destruction of this compound is reached. In fact, the only way to represent the experimental decrease observed in the concentration of ozone in discontinuous essays is by considering the formation of new species that behave as predators of ozone. Initially, they may correspond to many types of oxidants such as hydrogen peroxide or peroxosulfates, which interact with ozone following oxidantdepleting mechanisms that are well defined in the existing literature. The action of these species seems to be even more important in the understanding of the production of ozone than in the formation of other oxidants. Thus, the decomposition of ozone by persulfates and hydrogen peroxide with the initial formation of radicals and the final formation of oxygen has been reported by a number of authors [17,30-33], and it is known to develop process equations such as $\mathrm{p}_{4-1}$ and $\mathrm{p}_{4-2}$.

$$
\mathrm{O}_{3}+\mathrm{H}_{2} \mathrm{O}_{2} \rightarrow 2 \mathrm{O}_{2}+\mathrm{H}_{2} \mathrm{O}\left(\text { process } \mathrm{p}_{4-1}\right)
$$




$$
\mathrm{O}_{3}+\mathrm{SO}_{5}^{2-} \rightarrow 2 \mathrm{O}_{2}+\mathrm{SO}_{4}^{2-}\left(\text { process } \mathrm{p}_{4-2}\right)
$$

Initially, most of these oxidants involved in the decomposition of ozone share the -O-Ogroup and will be denoted in this work simply as peroxo species (named in the mathematical model as $S_{3}$ ), because a full characterization will be pointless as they are known to react fast with ozone once formed and hence, they cannot be properly determined from an analytical perspective. It is important to state that to the best of the authors' knowledge, the decrease observed in the production of ozone is not noticed in previous studies, which focused on the production of peroxosalts [27-29,34,35], ferrates [36], total chlorinated oxoanions $[37,38]$ or any other oxidant, and it indicates that ozone electrogeneration is a much more complex process. The kinetics of this process should depend on the concentration of this predator species and also on the concentration of ozone, and can be represented by Eq. 4, following a first-order kinetic as regards both reagents.

$$
r_{4}=-k_{4}\left[S_{1}\right]\left[S_{3}\right]
$$

One of the $\mathrm{S}_{3}$ species can be hydrogen peroxide. The formation of hydrogen peroxide is known to occur mostly on the cathode (process $\mathrm{p}_{5}$ ) by reduction of oxygen and competes with the reduction of water (process $\mathrm{p}_{6}$ ). For both processes, a zero-order kinetic model, as shown in eqs. 5 and 6 , can be proposed, where $r_{i}$ is production rate, $I$ is current intensity (A), $n$ is the number of electron transferred, $F$ is Faraday's constant $\left(96487 \mathrm{C} \mathrm{mol}^{-1}\right)$, while $\eta_{\mathrm{c} 1}$ and $\eta_{\mathrm{c} 2}$ indicate the fraction of the cathodic current used in each of these processes.

$$
\begin{gathered}
\mathrm{O}_{2}+2 \mathrm{H}^{+}+2 \mathrm{e}^{-} \rightarrow \mathrm{H}_{2} \mathrm{O}_{2}\left(\mathrm{p}_{5}\right) \\
2 \mathrm{H}_{2} \mathrm{O}+2 \mathrm{e}^{-} \rightarrow \mathrm{H}_{2}+2 \mathrm{OH}^{-}\left(\mathrm{p}_{6}\right) \\
r_{5}=\frac{I}{n_{5} F} \eta_{c 1}(5)
\end{gathered}
$$




$$
r_{6}=\frac{I}{n_{6} F} \eta_{c 2}(6)
$$

Conversely, the formation of peroxo species on the anode (either hydrogen peroxide, peroxodisulfate, peroxodicarbonates, etc.) competes with the oxidation of water to ozone, and it can also be modeled with the same type of kinetic equations (Eq. 7) in which the ratio of the current used in this process is named $\eta_{\mathrm{a} 3}$. In the experiments carried out in this work, the electrolyte only contained sulfates, which can lead to the formation of monoperoxosulfate or diperoxosulfate. Process $\mathrm{p}_{7}$ correspond of this reaction. In any case, regardless of the exact species formed, in the model proposed all oxidants are accounted for into model species $S_{3}$, because as stated before, further details are expected to be negligible, considering their rapid interaction with ozone and so their rapid disappearance from the system.

$$
\begin{gathered}
\mathrm{H}_{2} \mathrm{O}+\mathrm{SO}_{4}^{2-} \rightarrow 2 \mathrm{H}^{+}+2 \mathrm{e}^{-}+S O_{5}^{2-}\left(\mathrm{p}_{7}\right) \\
r_{o_{3}}=\frac{I}{n F} \eta_{a 3}(7)
\end{gathered}
$$

In addition, ozone can interact with oxidizable species contained in water (e.g., pollutants such as the clopyralid used in this work), as shown in process $\mathrm{p}_{8}$, and the kinetic model to represent this consumption should fit to Eq. 8. As in the case of predators, in order to simplify and focus only on ozone, in this first approach we are considering all organics and reaction intermediates included into a single model species called $\mathrm{S}_{4}$. The kinetic model proposed is also of first order regarding both model species.

$$
\begin{aligned}
\mathrm{O}_{3}+\text { Organic } & \rightarrow \mathrm{nCO}_{2}+m \mathrm{H}_{2} \mathrm{O}+\mathrm{O}_{2}+\cdots\left(\mathrm{p}_{8}\right) \\
r_{8} & =-k_{8}\left[S_{1}\right]\left[S_{4}\right](8)
\end{aligned}
$$

Furthermore, organics can be oxidized by the predator oxidant (process $\mathrm{p}_{9}$ ) or can be anodically oxidized on the electrode surface (process $\mathrm{p}_{10}$ ) competing with water oxidation 
to oxygen and ozone and with the anodic formation of predators -O-O-; it is possible to model these processes with a first-order kinetic respect to each reagent in the first case, whereas with a zero-order kinetic modified with a current distribution ratio $\eta_{\mathrm{a} 4}$, in the second.

$$
\begin{gathered}
\mathrm{SO}_{5}^{2-}+\text { Organic } \rightarrow \mathrm{nCO}_{2}+m \mathrm{H}_{2} \mathrm{O}+\mathrm{O}_{2}+\cdots\left(\mathrm{p}_{9}\right) \\
\text { Organics }-\mathrm{z}^{-} \rightarrow \mathrm{nCO}_{2}+m \mathrm{H}_{2} \mathrm{O}+\cdots\left(\mathrm{p}_{10}\right) \\
r_{9}=-k_{9}\left[S_{3}\right]\left[S_{4}\right] \\
r_{9}=\frac{I}{z F} \eta_{a 4}
\end{gathered}
$$

Obviously, the total sum of current distribution should be 1, both in the anode and in the cathode, as shown in eqs. 11 and 12.

$$
\begin{gathered}
\eta_{a 1}+\eta_{a 2}+\eta_{a 3}+\eta_{a 4}=1(11) \\
\eta_{c 1}+\eta_{c 2}=1(12)
\end{gathered}
$$

All these equations allow having a very simple phenomenological model, graphically shown in Figure 4, and summarized in Table 1 with a Pearson's matrix. 


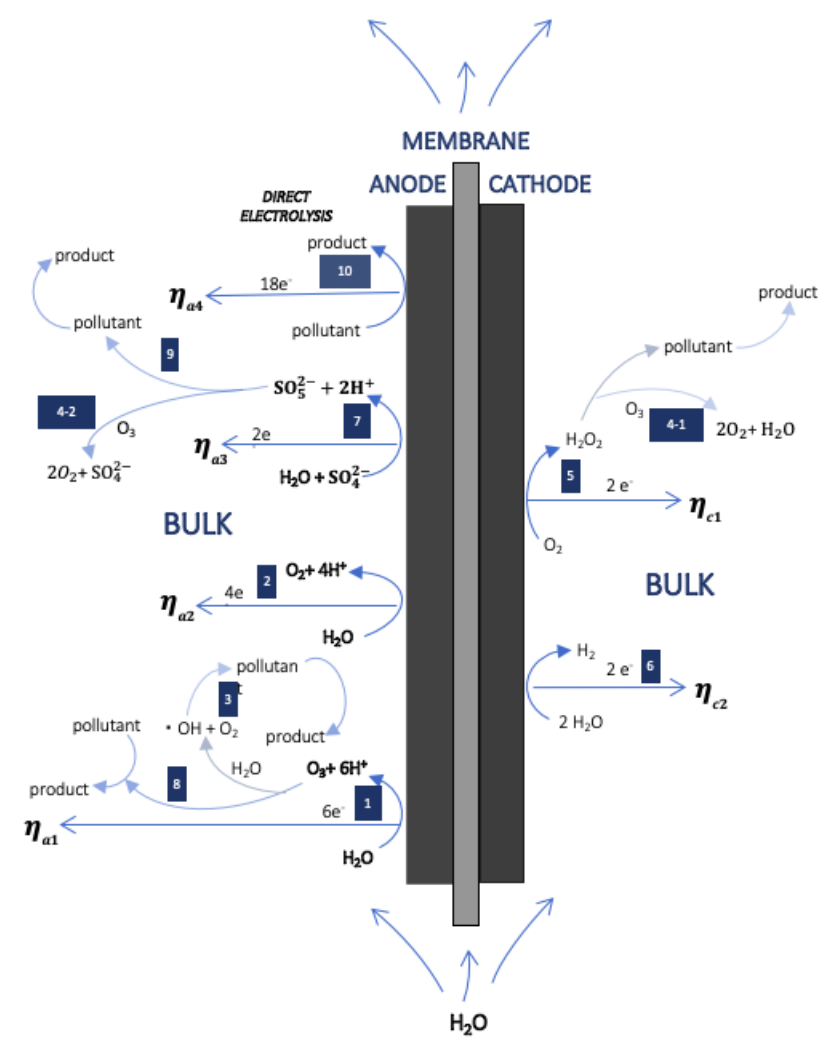

Figure 4. Graphical sketch of the model formulation.

Table 1. Pearson's matrix showing the kinetic and stoichiometry of the processes modeled

\begin{tabular}{|c|c|c|c|c|c|c|c|c|}
\hline Process/species & $\begin{array}{l}\mathrm{S}_{1} \\
\mathrm{O}_{3}\end{array}$ & $\begin{array}{l}\mathrm{S}_{2} \\
\mathrm{O}_{2}\end{array}$ & $\begin{array}{c}\mathrm{S}_{3} \\
\text { Predator } \\
\text { (-O-O-) }\end{array}$ & $\begin{array}{c}\mathrm{S}_{4} \\
\text { Organics }\end{array}$ & $\begin{array}{l}\mathrm{S}_{5} \\
\mathrm{H}_{2}\end{array}$ & $\begin{array}{c}\mathrm{S}_{6} \\
\mathrm{H}_{2} \mathrm{O}\end{array}$ & $\begin{array}{c}\mathrm{S}_{7} \\
\text { predator } \\
\text { precursor }\end{array}$ & Kinetics \\
\hline $\begin{array}{l}\mathrm{P}_{1} \text { : Electrochemical } \\
\text { production of ozone }\end{array}$ & +1 & & & & & -1 & & $\frac{I}{6 F} \eta_{a 1}$ \\
\hline $\begin{array}{c}P_{2}: \text { Electrochemical } \\
\text { production of ozone } \\
\text { oxygen }\end{array}$ & & +1 & & & & -1 & & $\frac{I}{4 F} \eta_{a 2}$ \\
\hline $\begin{array}{c}P_{3}: \text { Decomposition of } \\
\text { ozone }\end{array}$ & -1 & +1 & & & & & & $k_{3}\left[S_{1}\right]$ \\
\hline $\begin{array}{c}\mathrm{P}_{4} \text { : Decomposition of } \\
\text { ozone with peroxo } \\
\text { species }\end{array}$ & -1 & +1 & -1 & & & & & $k_{4}\left[S_{1}\right]\left[S_{3}\right]$ \\
\hline $\begin{array}{l}P_{5}: \text { Cathodic formation of } \\
\text { predator species }\end{array}$ & & -1 & +1 & & & & & $\frac{I}{2 F} \eta_{c 1}$ \\
\hline $\begin{array}{c}\mathbf{P}_{6}: \text { Reduction of water to } \\
\text { hydrogen }\end{array}$ & & & & & 1 & -1 & & $\frac{I}{2 F} \eta_{c 2}$ \\
\hline $\begin{array}{c}\mathrm{P}_{7}: \text { Anodic production of } \\
\text { predator species }\end{array}$ & & & +1 & & & -1 & -1 & $\frac{I}{2 F} \eta_{a 3}$ \\
\hline $\begin{array}{c}P_{8}: \text { Oxidation of organics } \\
\text { by ozone }\end{array}$ & -1 & & & -1 & & & & $k_{8}\left[S_{1}\right]\left[S_{4}\right]$ \\
\hline $\begin{array}{c}P_{9}: \text { oxidation of organics } \\
\text { by predator }\end{array}$ & & & -1 & -1 & & & & $k_{9}\left[S_{3}\right]\left[S_{4}\right]$ \\
\hline $\begin{array}{c}\mathbf{P}_{10}: \text { Direct } \\
\text { electrochemical oxidation } \\
\text { of organics }\end{array}$ & & & & -1 & & & & $\frac{I}{z F} \eta_{a 4}$ \\
\hline
\end{tabular}


The application of this model in a continuous setup results in Equation 12 (one for each species j), while in a discontinuous setup, in Equation 13 (also one for each species j). Where $\left[S_{j}\right]$ is the concentration of the species $j ; \mu_{i, j}$ is the stoichiometric coefficient of species $\mathrm{j}$ in reaction $\mathrm{i}$ as shown in Pearson's matrix; $r_{i}$ is the reaction rate of process $i$; $V$ is the electrolyte volume; and, $\mathrm{q}$ is flow rate.

$$
\begin{gathered}
V \frac{d\left[S_{j}\right]}{d t}=q\left(\left[S_{j}\right]_{0}-\left[S_{j}\right]_{1}\right)+\sum_{i=1}^{p} \mu_{i, j} r_{i} \\
V \frac{d\left[S_{j}\right]}{d t}=\sum_{i=1}^{p} \mu_{i, j} r_{i}(13)
\end{gathered}
$$

In order to validate the model, it will be used in the reproduction of experimental data in the following sections, and so the assumptions on which it is based will be verified.

Influence of operation mode. Figure 5 compares experimental and simulated results for the production of ozone in continuous and discontinuous modes. Also, empty points in Figure 3 correspond to the simulation of steady state concentrations reached in the experimental system using the same parameters as in Figure 5 for continuous operation. Values of fitting parameters used for these simulations are shown in Table 2 (two first rows). As seen, the rather good agreement between the experimental and simulated results helps to validate the hypothesis proposed. In discontinuous operation, the model explains that the production of ozone reaches a maximum and then it decreases, relating this change to two facts, ozone decomposition by saturation of ozone dissolved in water and formation and interaction of predator species with ozone. Thus, to achieve better ozone stability, it is necessary to prevent both phenomena by means of controlling different operational parameters. Regarding model parameters, it is important to see that for all the parameters related to chemical processes, the same value can be used for a good fitting. As for electrochemical parameters, the higher value required for $\eta_{c 1}$ (production of hydrogen peroxide) can be explained in terms of the higher 
concentrations of oxygen reached in discontinuous operation mode (which is the cathodic precursor of hydrogen peroxide), owing to the accumulation of this species by the recycling of the effluent of the cell to the reservoir tank from which it is fed again into the cell. In relation to $\eta_{a 1}$, its lower value in continuous mode may indicate that oxygen concentration possibly plays a catalytic role in the production of ozone, following equation $\mathrm{p}_{11}$, though in the literature it is clearly stated that ozone production at mild conditions only uses water as raw matter, not oxygen [1].

$$
\mathrm{H}_{2} \mathrm{O}+\mathrm{O}_{2} \rightarrow \mathrm{O}_{3}+2 \mathrm{H}^{+}+2 \mathrm{e}^{-}\left(p_{11}\right)
$$

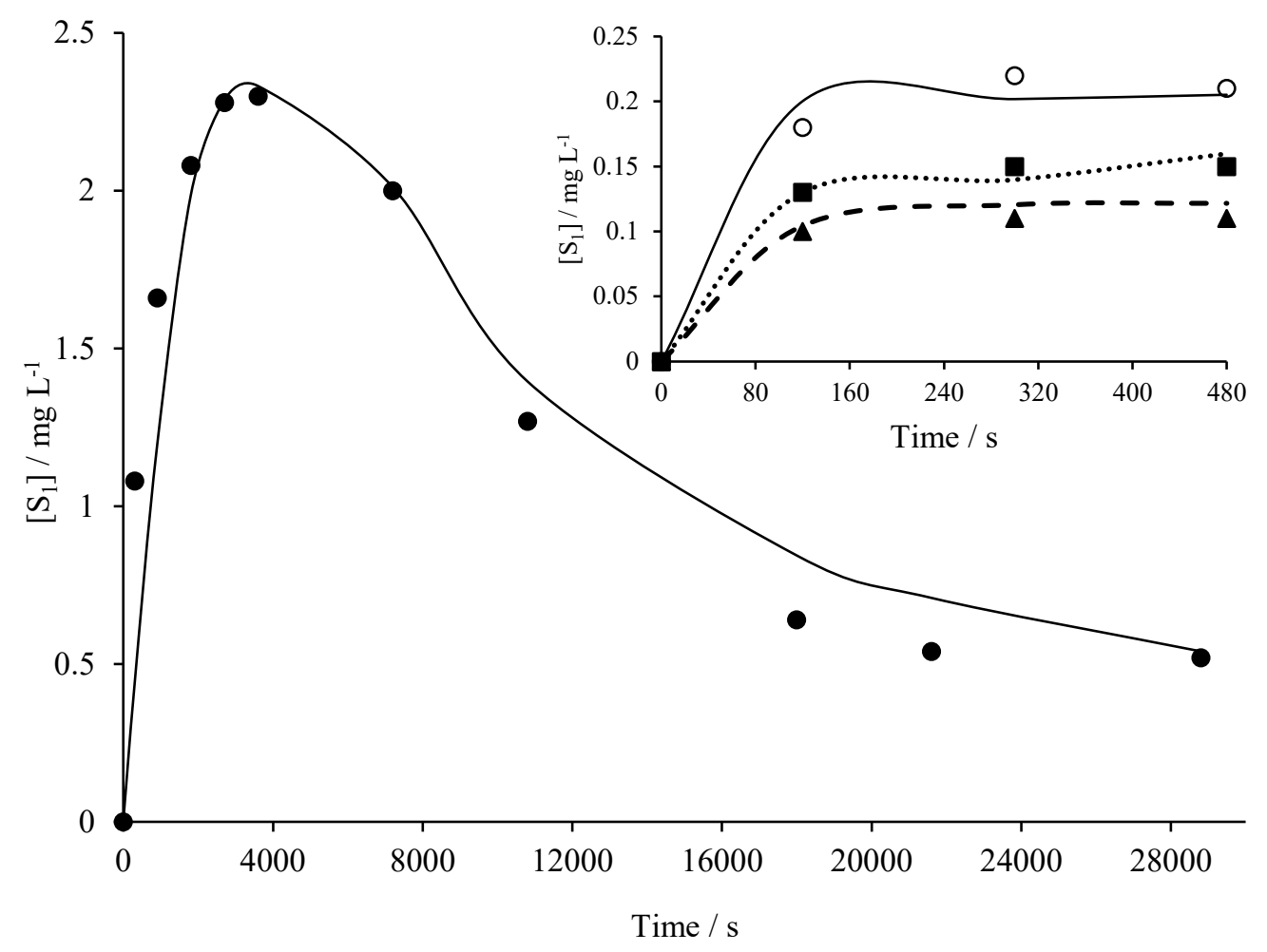

Figure 5. Ozone electrogeneration in discontinuous mode: $(\bullet)$ experimental, $(-)$ model. Onset: Ozone electrogeneration in continuous mode: (०) $3 \mathrm{~L} \mathrm{~min}^{-1}$ experimental,

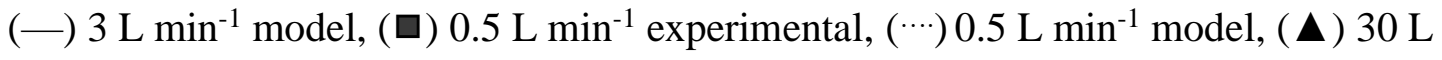
min ${ }^{-1}$ experimental, (---) $30 \mathrm{~L} \mathrm{~min}^{-1}$ model. (Conditions: $10 \mathrm{~A}, \mathrm{Na}_{2} \mathrm{SO}_{4}, \mathrm{pH} 6.8$ ). 
Table 2. Fitting parameter used for the simulations shown in Figure 5

\begin{tabular}{|c|c|c|c|c|c|c|c|c|c|c|c|c|c|}
\hline Operation mode & $\mathbf{j}$ & {$\left[\mathbf{S}_{4}\right]$} & $\mathrm{k}_{3}\left(\mathrm{~s}^{-1}\right)$ & $\mathrm{k}_{4}\left(\mathrm{~s}^{-1}\right)$ & $\mathrm{k}_{8}\left(\mathrm{~s}^{-1}\right)$ & $\mathrm{k}_{9}\left(\mathrm{~s}^{-1}\right)$ & & & & & & & \\
& (A) & $\mathbf{m g ~ \mathbf { L } ^ { - 1 }}$ & $10^{-4}$ & $10^{-4}$ & $10^{-5}$ & $10^{-4}$ & $\eta_{a 1}$ & $\eta_{a 2}$ & $\eta_{a 3}$ & $\eta_{a 4}$ & $\eta_{c 1}$ & $\eta_{c 2}$ & $\mathrm{r}^{2}$ \\
\hline continuous & $\mathbf{1 0}$ & $\mathbf{0}$ & 1.133 & 8.391 & 1.110 & 9.035 & 0.2 & 0.6 & 0.2 & $-(0)$ & 0.2 & 0.8 & 0.92 \\
\hline discontinuous & $\mathbf{1 0}$ & $\mathbf{0}$ & 1.133 & 8.391 & 1.110 & 9.035 & 0.65 & 0.1 & 0.25 & $-(0)$ & 0.7 & 0.3 & 0.9 \\
\hline
\end{tabular}

Influence of current density. Figure 6 shows the effect of current density on the production of ozone in discontinuous mode and how the model proposed fits the experimental data well, also keeping the value of the parameters of the chemical processes, which indicates the robustness of the model. Values of fitting parameters are shown in Table 3. The electrochemical production of ozone is faster with a higher applied current intensity, as in such conditions, it achieves higher cell potential promoting ozone production over oxygen as it is stated in parameter $\eta_{a 1}$. Decreases observed in parameter $\eta_{c 1}$ (production of hydrogen peroxide) at higher current densities can be explained by the harsh conditions on the surface of the cathode, which promote the production of water instead of hydrogen peroxide from the reduction of oxygen. However, current intensity does not improve the stability of ozone because in the three cases ozone concentration decreases after reaching a maximum value.

Table 3. Fitting parameter used for the simulations shown in Figure 6

\begin{tabular}{|c|c|c|c|c|c|c|c|c|c|c|c|c|c|}
\hline Operation mode & $\begin{array}{c}\mathbf{j} \\
\text { (A) }\end{array}$ & $\begin{array}{c}{\left[\mathrm{S}_{4}\right]} \\
\mathrm{mg} \mathrm{L}^{-1}\end{array}$ & $\begin{array}{c}\mathrm{k}_{3}\left(\mathrm{~s}^{-1}\right) \\
10^{-4}\end{array}$ & $\begin{array}{c}\mathrm{k}_{4}\left(\mathrm{~s}^{-1}\right) \\
10^{-4}\end{array}$ & $\begin{array}{c}\mathrm{k}_{8}\left(\mathrm{~s}^{-1}\right) \\
10^{-5}\end{array}$ & $\begin{array}{c}\mathrm{k}_{9}\left(\mathrm{~s}^{-1}\right) \\
10^{-4}\end{array}$ & $\eta_{a 1}$ & $\eta_{a 2}$ & $\eta_{a 3}$ & $\eta_{a 4}$ & $\eta_{c 1}$ & $\eta_{c 2}$ & $r^{2}$ \\
\hline discontinuous & 10 & $\mathbf{0}$ & 1.133 & 8.391 & 1.110 & 9.035 & 0.65 & 0.1 & 0.25 & $-(0)$ & 0.7 & 0.3 & 0.9 \\
\hline discontinuous & 8 & $\mathbf{0}$ & 1.133 & 8.391 & 1.110 & 9.035 & 0.45 & 0.35 & 0.2 & $-(0)$ & 0.4 & 0.6 & 0.9 \\
\hline discontinuous & 7 & $\mathbf{0}$ & 1.133 & 8.391 & 1.110 & 9.035 & 0.40 & 0.50 & 0.10 & - $(0)$ & 0.2 & 0.8 & 0.9 \\
\hline
\end{tabular}




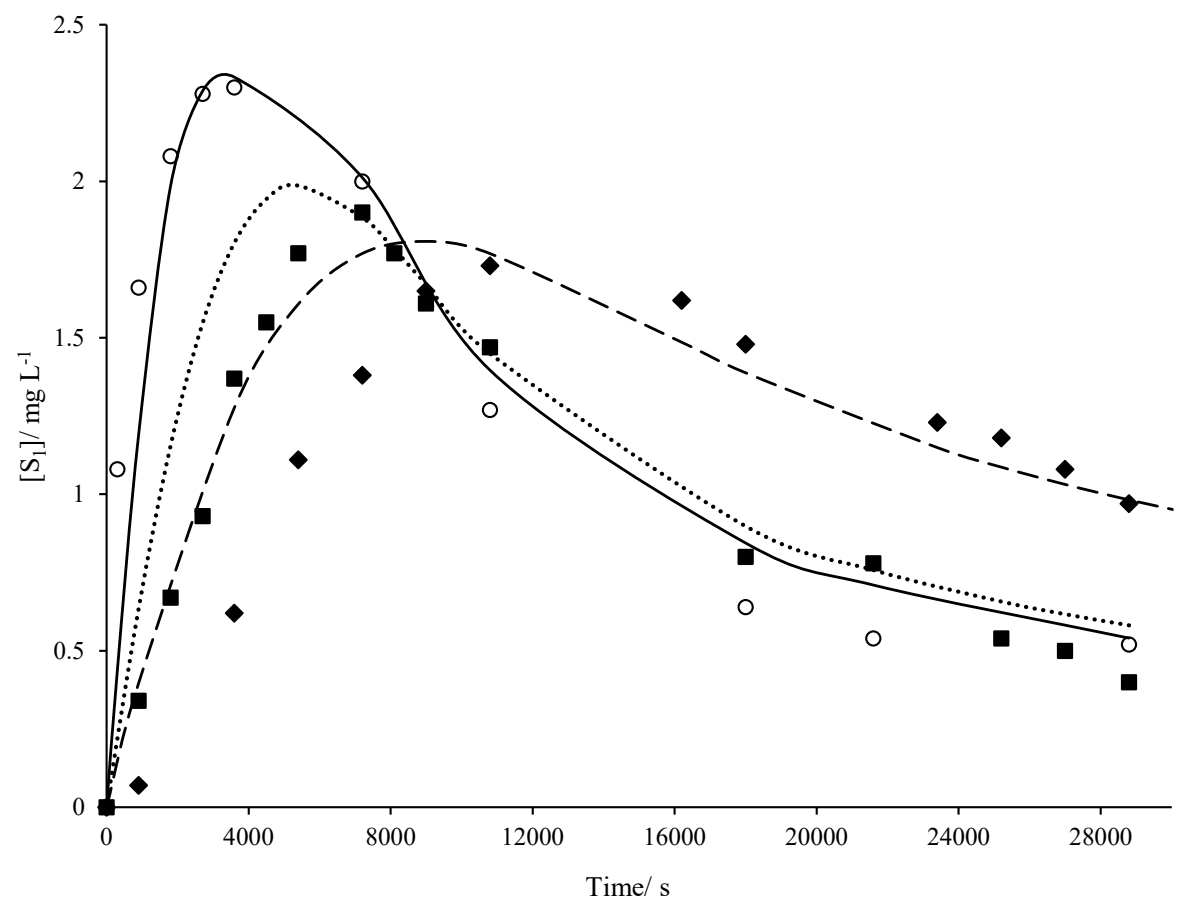

Figure 6. Influence of current applied on ozone electrogeneration in discontinuous

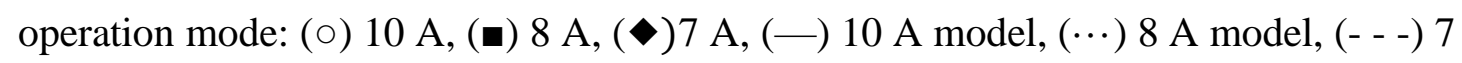
A model (conditions: pH 6.8).

Oxidation of organic pollutants. Figure 7 compares the changes in the concentration of ozone when an organic compound is added to the electrolyte in which ozone is produced. In this case, which simulates wastewater treatment, the concentrations of ozone accumulated in the electrolyte are lower, indicating that ozone reacts with clopyralid (selected as organic target). This is observed in part $b$ of the figure, where the concentration of this compound is shown, as well as its mineralization (which the model considers assuming the very small production of detectable intermediates at the very low concentrations used). The part $\mathrm{c}$ of the Figure shows the $\mathrm{mg}$ of TOC removed per $\mathrm{mg}$ of $\mathrm{O}_{3}$ consumed and shows that, after the first moments, this value stabilizes at

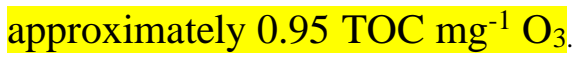


As it is known, ozone is an unstable oxidizing gas with a maximum half-life in clean water in the order of only a few hours, which is reduced when pollutants are present because it is being used to degrade them. Thus, ozone is not only decomposed chemically or by the action of other electrogenerated oxidants, as proposed by the processes modeled before, but it is also decomposed during the oxidation of organics. Indeed, when the organic is totally degraded, ozone and predator species are still available, and ozone concentration remains decreasing.

As seen in the different lines shown in Figure 7 (simulations), the model proposed also fits well the production of ozone and the degradation of total organic carbon (TOC) during the test. Constants used in the simulation are shown in Table 4, being important to highlight that all the parameters used for the simulation in the absence of clopyralid were successfully applied in the presence of the organics and that the experimental results are perfectly fitted only by considering that the value of $\eta_{a 3}$ in the system in the absence of organics is transformed into $\eta_{a 3}$ and $\eta_{a 4}$ in the system in the presence of organics, pointing out again the robustness of the model.
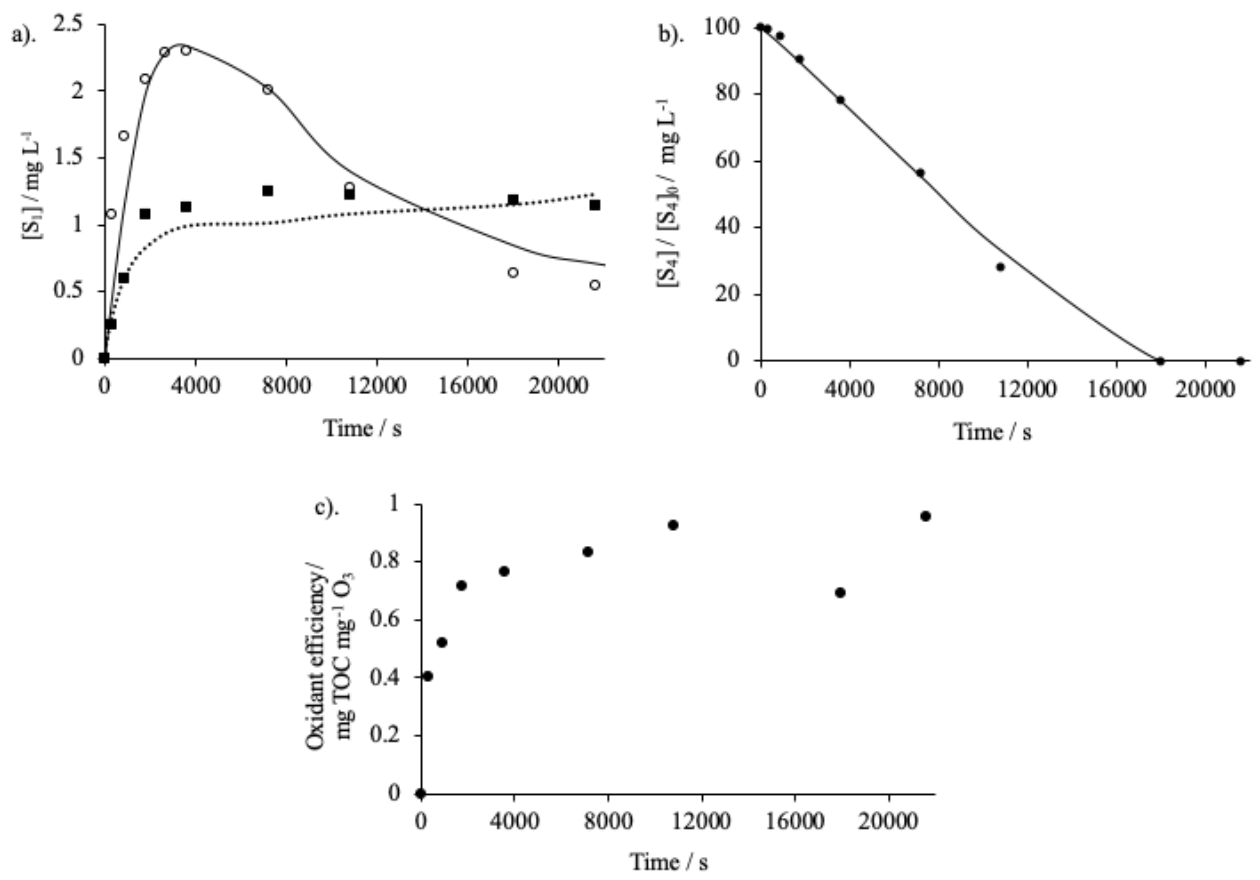
Figure 7. a) Concentration of ozone electrogenerated in absence ( $\mathrm{e}$ experimental, model) and presence ( $\square$ experimental, $\cdots$ model) of clopyralid. b) Removal of clopyralid (• experimental, — model concentration). c) Oxidant efficiency (Conditions: pH 6.8, 10 A).

Table 4. Fitting parameter used for the simulations shown in Figure 7

\begin{tabular}{|l|c|c|c|c|c|c|c|c|c|c|c|c|c|}
\hline Operation mode & $\mathbf{j}$ & $\mathbf{[ \mathbf { S } _ { 4 } ]}$ & $\mathrm{k}_{3}\left(\mathrm{~s}^{-1}\right)$ & $\mathrm{k}_{4}\left(\mathrm{~s}^{-1}\right)$ & $\mathrm{k}_{8}\left(\mathrm{~s}^{-1}\right)$ & $\mathrm{k}_{9}\left(\mathrm{~s}^{-1}\right)$ & & & & & & & \\
& (A) & $\mathbf{m g} \mathbf{L}^{-1}$ & $10^{-4}$ & $10^{-4}$ & $10^{-5}$ & $10^{-4}$ & $\eta_{a 1}$ & $\eta_{a 2}$ & $\eta_{a 3}$ & $\eta_{a 4}$ & $\eta_{c 1}$ & $\eta_{c 2}$ & $\mathrm{r}^{2}$ \\
\hline discontinuous & $\mathbf{1 0}$ & $\mathbf{0}$ & 1.133 & 8.391 & 1.110 & 9.035 & 0.65 & 0.1 & 0.25 & $-(0)$ & 0.7 & 0.3 & 0.9 \\
\hline discontinuous & $\mathbf{1 0}$ & $\mathbf{1 0 0}$ & 1.133 & 8.391 & 1.110 & 9.035 & 0.65 & 0.1 & 0.15 & 0.1 & 0.7 & 0.3 & 0.94 \\
\hline
\end{tabular}

Model validation. Figure 8 shows the plot experimental versus simulated data for the results discussed in this work. As observed, the model satisfactorily reproduces the production of ozone in mild $\mathrm{pH}$ conditions with a regression coefficient which ranges between 0.88 and 0.99 . The good fittings obtained with almost the same set of parameters indicate that the model assumptions taken during its formulation are suitable and explain well the experimental behavior observed.

TOC experimental / $\mathrm{mg} \mathrm{L}^{-1}$

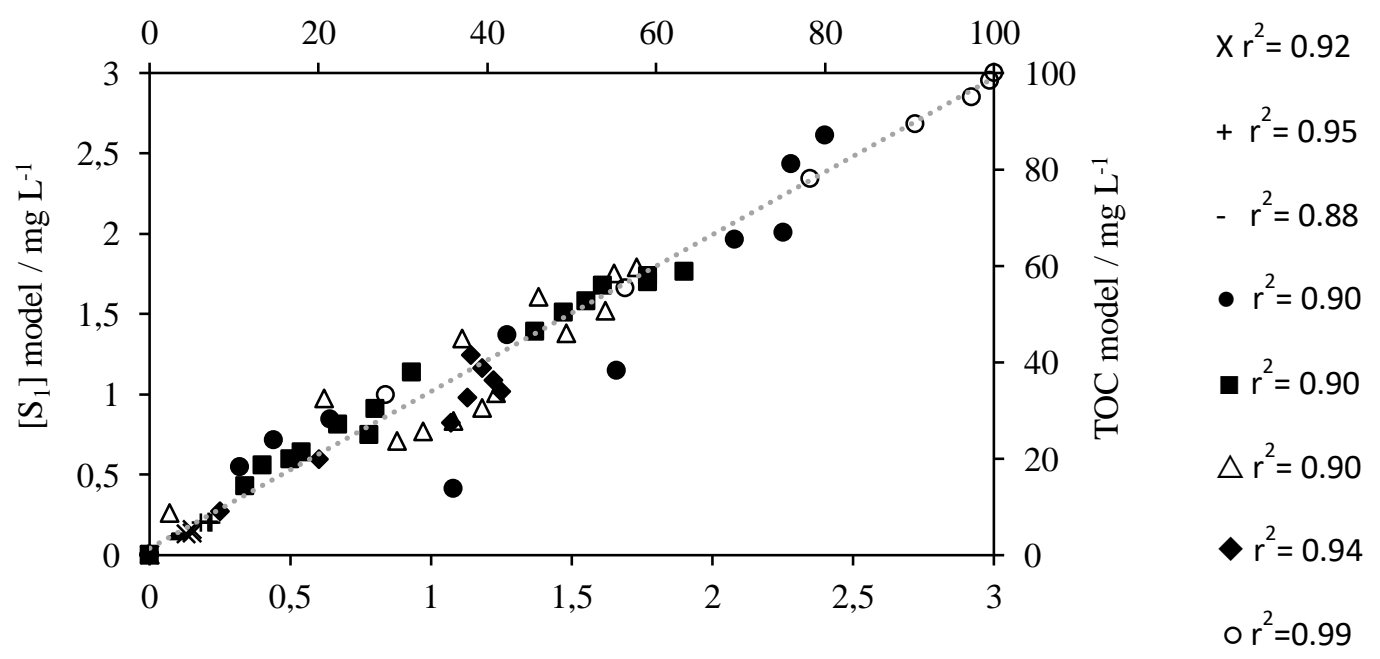

$\left[\mathrm{S}_{1}\right]$ experimental / $\mathrm{mg} \mathrm{L}^{-1}$ 
Figure 8. Experimental data for ozone electrogeneration and TOC removal: (x) continuous $3 \mathrm{~L} \mathrm{~min}^{-1}$; (+) continuous $0.5 \mathrm{~L} \mathrm{~min}^{-1}$; (-) continuous, $30 \mathrm{~L} \mathrm{~min}{ }^{-1} ;(\bullet) 10 \mathrm{~A}$ discontinuous; ( $(\mathbf{a})$ 8A discontinuous; $(\triangle)$ 7A discontinuous; $(\bullet)$ discontinuous 10A;

(o) TOC removal in discontinuous mode at 10A

\section{Conclusions}

From this work, the following conclusions can be drawn:

- PEM electrolyzer is able to generate ozone at neutral $\mathrm{pH}$ in continuous and discontinuous mode. However, in discontinuous mode the ozone generated decomposes faster over time, due to the electrochemical production of predator species that destroy the ozone generated. This phenomenon can be partially prevented by operating the cell in continuous mode, where the ozone generated leaves the system minimizing the electrochemical destruction of the oxidant produced.

- A very simple model can describe ozone generation from the electrochemical oxidation of water and a very low set of fitting parameters. This model considers the formation of predators, such as hydrogen peroxide and other peroxo species, which interact rapidly with ozone producing oxygen. Also, the chemical decomposition of ozone and the effects of the interactions of ozone with organic matter are taken into consideration.

- The model reproduces the operation performance of the electro-ozonator in continuous and discontinuous modes, the effect of current density and the effect of the presence of clopyralid in the system. The model indicates that oxygen can play an important role in the production of ozone, as a promoter in the production of hydrogen peroxide and as a promoter in the formation of ozone from the oxidation of water as well. 



\section{Acknowledgements}

Financial support from Spain's Agencia Estatal de Investigación through project PID2019-107271RB-I00 is gratefully acknowledged. Mayra Rodriguez also acknowledges CONACYT 722138.

\section{References}

[1] A.R. Rahmani, D. Nematollahi, M.R. Samarghandi, M.T. Samadi, G. Azarian, A central composite design to optimize in-situ electrochemically produced ozone for removal of reactive red 198, J. Electrochem. Soc. 165 (2018) E121-E128. https://doi.org/10.1149/2.0201803jes.

[2] C. Rosales, C.E. Barrera, A. Amaya, G. Roa, Evaluation of a coupled system of electro-oxidation and ozonation to remove the pesticide Thiodan Ò $35 \mathrm{CE}$ ( endosulfan ) in aqueous solution, Fuel. (2016) 6-13. https://doi.org/10.1016/j.fuel.2016.10.031.

[3] L. Varga, J. Szigeti, Use of ozone in the dairy industry: A review, Int. J. Dairy Technol. 69 (2016) 157-168a. https://doi.org/10.1111/1471-0307.12302.

[4] R. Broséus, S. Vincent, K. Aboulfadl, A. Daneshvar, S. Sauvé, B. Barbeau, M. Prévost, Ozone oxidation of pharmaceuticals, endocrine disruptors and pesticides during drinking water treatment, Water Res. 43 (2009) 4707-4717. https://doi.org/10.1016/j.watres.2009.07.031.

[5] K. Kitsuka, K. Kaneda, M. Ikematsu, M. Iseki, K. Mushiake, T. Ohsaka, Ex situ and in situ characterization studies of spin-coated $\mathrm{TiO} 2$ film electrodes for the electrochemical ozone production process, Electrochim. Acta. 55 (2009) 31-36. 
https://doi.org/10.1016/j.electacta.2009.07.059.

[6] Y.-H. Wang, Q.-Y. Chen, Anodic Materials for Electrocatalytic Ozone Generation, Int. J. Electrochem. 2013 (2013) 1-7. https://doi.org/10.1155/2013/128248.

[7] Y. Yan, Y. Gao, H. Zheng, B. Yuan, Q. Zhang, Y. Gu, G. Zhuang, Z. Wei, Z. Yao, X. Zhong, X. Li, J. Wang, Simultaneous electrochemical ozone production and hydrogen evolution by using tantalum-based nanorods electrocatalysts, Appl. Catal. B Environ. 266 (2020). https://doi.org/10.1016/j.apcatb.2020.118632.

[8] Y. Meas, L.A. Godinez, E. Bustos, Ozone Generation Using Boron-Doped Diamond Electrodes, in: Synth. Diam. Film. Prep. Electrochem. Charact. Appl., Wiley Online Library, 2011: pp. 311-331. https://doi.org/10.1002/9781118062364.ch13.

[9] A.R. Rahmani, G. Azarian, D. Nematollahi, New insights into electrocatalytic ozone generation using $\mathrm{Pt} / \mathrm{Ni}-\mathrm{Sb}-\mathrm{SnO} 2$ and $\mathrm{GC} / \mathrm{Ni}-\mathrm{Sb}-\mathrm{SnO} 2$ electrodes, J. Electroanal. $\quad$ Chem. $\quad 824 \quad$ (2018) 216-225. https://doi.org/10.1016/j.jelechem.2018.07.050.

[10] A.R. Rahmani, D. Nematollahi, M.T. Samadi, M.R. Samarghandi, Ghasemazarian, Electrochemical preparation of the Ti/Ni-Sb-SnO2 for removal of phenol, in situ generated ozone, Orient. J. Chem. 34 (2018) 757-763. https://doi.org/10.13005/ojc/340219.

[11] L.G. De Sousa, D. V. Franco, L.M. Da Silva, Electrochemical ozone production using electrolyte-free water for environmental applications, J. Environ. Chem. Eng. 4 (2016) 418-427. https://doi.org/10.1016/j.jece.2015.11.042.

[12] P.A. Christensen, T. Yonar, K. Zakaria, The Electrochemical Generation of Ozone: A Review, Ozone Sci. Eng. $35 \quad$ (2013) 149-167. 
https://doi.org/10.1080/01919512.2013.761564.

[13] F. Okada, S. Tanaka, S. Tanaka, K. Naya, Electrochemical production of $70 \mathrm{wt}$ ppm ozone water, Electrochim. Acta. $153 \quad$ (2015) 210-216. https://doi.org/10.1016/j.electacta.2014.12.010.

[14] C. Zhang, Y. Xu, P. Lu, X. Zhang, F. Xu, J. Shi, Capillary Effect-Enabled Water Electrolysis for Enhanced Electrochemical Ozone Production by Using Bulk Porous Electrode, J. Am. Chem. Soc. 139 (2017) 16620-16629. https://doi.org/10.1021/jacs.7b07705.

[15] M. Rajab, C. Heim, T. Letzel, J.E. Drewes, B. Helmreich, Electrochemical disinfection using boron-doped diamond electrode - The synergetic effects of in situ ozone and free chlorine generation, Chemosphere. 121 (2015) 47-53. https://doi.org/10.1016/j.chemosphere.2014.10.075.

[16] C. Sáez, M.A. Rodrigo, A.S. Fajardo, C.A. Martínez-Huitle, Indirect electrochemical oxidation by using ozone, hydrogen peroxide, and ferrate, Electrochem. Water Wastewater Treat. (2018) 165-192. https://doi.org/10.1016/B978-0-12-813160-2.00007-9.

[17] J.A. Lara-Ramos, C. Saez, F. Machuca-Martínez, M.A. Rodrigo, Electroozonizers: A new approach for an old problem, Sep. Purif. Technol. 241 (2020). https://doi.org/10.1016/j.seppur.2020.116701.

[18] A. Kraft, M. Stadelmann, M. Wünsche, M. Blaschke, Electrochemical ozone production using diamond anodes and a solid polymer electrolyte, Electrochem. Commun. 8 (2006) 883-886.

[19] J. Isidro, D. Brackemeyer, C. Sáez, J. Llanos, J. Lobato, P. Cañizares, T. Matthée, M.A. Rodrigo, Electro-disinfection with BDD-electrodes featuring PEM 
$\begin{array}{llllll}\text { technology, } & \text { Sep. } & \text { Purif. } & \text { Technol. } & 248 & \text { (2020) }\end{array}$ https://doi.org/10.1016/j.seppur.2020.117081.

[20] J. Isidro, D. Brackemeyer, C. Sáez, J. Llanos, J. Lobato, P. Cañizares, T. Matthée, M.A. Rodrigo, How to avoid the formation of hazardous chlorates and perchlorates during electro-disinfection with diamond anodes?, J. Environ. Manage. 265 (2020). https://doi.org/10.1016/j.jenvman.2020.110566.

[21] J. Isidro, D. Brackemeyer, C. Sáez, J. Llanos, J. Lobato, P. Cañizares, T. Matthée, M.A. Rodrigo, Testing the use of cells equipped with solid polymer electrolytes for electro-disinfection, Sci. Total Environ. $725 \quad$ (2020) 138379. https://doi.org/10.1016/j.scitotenv.2020.138379.

[22] J. Isidro, D. Brackemeyer, C. Sáez, J. Llanos, J. Lobato, P. Cañizares, T. Matthee, M.A. Rodrigo, Operating the $\mathrm{CabECO}{ }^{\circledR}$ membrane electrolytic technology in continuous mode for the direct disinfection of highly fecal-polluted water, Sep. Purif. Technol. $\quad 208 \quad$ (2019) 110-115. https://doi.org/10.1016/j.seppur.2018.04.070.

[23] E. Rischbieter, H. Stein, A. Schumpe, Ozone solubilities in water and aqueous salt solutions, J. Chem. Eng. Data. $45 \quad$ (2000) 338-340. https://doi.org/10.1021/je990263c.

[24] L.M. Da, L.A. De Faria, J.F.C. Boodts, Electrochemical ozone production: influence of the supporting electrolyte on kinetics and current efficiency, 48 (2003) 699-709.

[25] M. Qadafi, S. Notodarmojo, Y. Zevi, Effects of microbubble pre-ozonation time and $\mathrm{pH}$ on trihalomethanes and haloacetic acids formation in pilot-scale tropical peat water treatments for drinking water purposes, Sci. Total Environ. 747 (2020). https://doi.org/10.1016/j.scitotenv.2020.141540. 
[26] G.O.S. Santos, K.I.B. Eguiluz, G.R. Salazar-Banda, C. Saez, M.A. Rodrigo, Photoelectrolysis of clopyralid wastes with a novel laser-prepared MMORuO2TiO2 anode, Chemosphere. $244 \quad$ (2020). https://doi.org/10.1016/j.chemosphere.2019.125455.

[27] E. Weiss, C. Sáez, K. Groenen-Serrano, P. Canizares, A. Savall, M.A. Rodrigo, Electrochemical synthesis of peroxomonophosphate using boron-doped diamond anodes, J. Appl. Electrochem. 38 (2008) 93-100.

[28] P. Canizares, F. Larrondo, J. Lobato, M.A. Rodrigo, C. Sáez, Electrochemical synthesis of peroxodiphosphate using boron-doped diamond anodes, J. Electrochem. Soc. 152 (2005) D191-D196.

[29] S. Velazquez-Pena, C. Sáez, P. Canizares, I. Linares-Hernández, V. MartínezMiranda, C. Barrera-Díaz, M.A. Rodrigo, Production of oxidants via electrolysis of carbonate solutions with conductive-diamond anodes, Chem. Eng. J. 230 (2013) $272-278$.

[30] C. Qu, S. Lu, D. Liang, S. Chen, Y. Xiang, S. Zhang, Simultaneous electrooxidation and in situ electro-peroxone process for the degradation of refractory organics in wastewater, J. Hazard. Mater. 364 (2019) 468-474. https://doi.org/10.1016/j.jhazmat.2018.10.073.

[31] J. Zhan, Z. Li, G. Yu, X. Pan, J. Wang, W. Zhu, X. Han, Y. Wang, Enhanced treatment of pharmaceutical wastewater by combining three- dimensional electrochemical process with ozonation to in situ regenerate granular activated carbon particle electrodes, Sep. Purif. Technol. 208 (2019) 12-18. https://doi.org/10.1016/j.seppur.2018.06.030.

[32] J. Wang, H. Chen, Catalytic ozonation for water and wastewater treatment: Recent advances and perspective, Sci. Total Environ. 704 (2020) 135249. 
https://doi.org/10.1016/j.scitotenv.2019.135249.

[33] H. Wang, J. Zhan, W. Yao, B. Wang, S. Deng, J. Huang, G. Yu, Y. Wang, Comparison of pharmaceutical abatement in various water matrices by conventional ozonation, peroxone $(\mathrm{O} 3 / \mathrm{H} 2 \mathrm{O} 2)$, and an electro-peroxone process, Water Res. 130 (2018) 127-138. https://doi.org/10.1016/j.watres.2017.11.054.

[34] S. Cotillas, A. Sánchez-Carretero, P. Cañizares, C. Sáez, M.A. Rodrigo, Electrochemical synthesis of peroxyacetic acid using conductive diamond electrodes, Ind. Eng. Chem. Res. 50 (2011) 10889-10893. https://doi.org/10.1021/ie2009422.

[35] J. Llanos, I. Moraleda, C. Sáez, M.A. Rodrigo, P. Cañizares, Reactor design as a critical input in the electrochemical production of peroxoacetic acid, J. Chem. Technol. Biotechnol. 94 (2019) 2955-2960. https://doi.org/10.1002/jctb.6101.

[36] P. Cañizares, M. Arcís, C. Sáez, M.A. Rodrigo, Electrochemical synthesis of ferrate using boron doped diamond anodes, Electrochem. Commun. 9 (2007) 2286-2290. https://doi.org/10.1016/j.elecom.2007.06.034.

[37] A. Sánchez-Carretero, C. Sáez, P. Cañizares, M.A. Rodrigo, Electrochemical production of perchlorates using conductive diamond electrolyses, Chem. Eng. J. 166 (2011) 710-714. https://doi.org/10.1016/j.cej.2010.11.037.

[38] J. Llanos, I. Moraleda, C. Sáez, M.A. Rodrigo, P. Cañizares, Electrochemical production of perchlorate as an alternative for the valorization of brines, Chemosphere. 220 (2019) 637-643. https://doi.org/10.1016/j.chemosphere.2018.12.153. 